\title{
試験出題部分の講義資料内での予告が 看護学生の学習意欲に与える影響
}

\author{
星 野 綾 美, ${ }^{1}$ 坂 本 浩之助, ${ }^{2}$ 田 村 遵一 ${ }^{1}$ \\ 瀬 戸 正子 2
}

\section{要 旨}

【背景・目的】看護学生は, 短期間で幅広い専門的知識を習得しなければならず, 高い学習意欲が要求されて いる. 我々は実習に先立つ講義において, 試験出題部分をあらかじめ講義資料の中で明示することが, 看護学 生の学習意欲に及ぼす影響を検討した。【対象と方法】 2004 年度入学の看護学科一年次の学生 (男性 12 名, 女性 72 名). 試験に出題する部分を講義資料のなかで明示し, 学習意欲について, Visual analogue scale で定量 化した.【結 果】 試験出題部分を予告した今回の講義の方が，予告をしない他の講義より Visual Analogue Scale を用いて定量した学習意欲が有意に高かった. 自由筆記の分析からは, 「実習で学習内容を実践す るのが楽しみになった」など, 学習意欲に関する項目が抽出された。【結 論】 試験出題部分の講義資料内 での予告は, 看護学生の学習意欲を向上させる一手段として有用であると考元られた. (Kitakanto Med J $2006 ; 56: 313 \sim 318)$

キーワード：試験出題部分の予告, 配布資料, 学習意欲, 看護学生

\section{は じめに}

看護学生は, 短期間で幅広い専門的知識を習得しなけ ればならず, 学生には高い学習意欲が要求されている. しかし, 教育の現場からは, 学生が時間をかけて学習し ているにもかかわらず, 集中力の不足や学習方法そのも のに問題があるため, 効果があがっていないとの指摘が ある. ${ }^{1}$ この問題を解決するためには, 学生が講義に集中 でき, 効果的な学習の手順が容易に理解できるよう講義 を工夫する必要があると考えた，そこで，今回われわれ は，試験に出題する部分をあらかじめ講義資料内に明示 することが, 学生の学習意欲, 学習時間, 達成感などにど のような影響を及ぼすか検討した。

\section{方法}

高崎健康福祉大学短期大学部看護学科一年次の学生 (男性 12 名, 女性 72 名) を対象とした. 対象科目は「へル スアセスメント論」(週 1 回 90 分, 全 4 回) であり, 引き 続き行われる「ヘルスアセスメント実習」のため, 診察技
法の裏付けとなる最低限の用語や知識を身につけること を目標とした講義形式の授業である.

講義の際, 毎回講義資料を配布し, 講義は資料に沿つ て進行した. 資料の中では, 重要な箇所は太字とし, 最重 要であり, 試験に出題する部分 83 箇所を太字の斜体か つ下線付きとして明示し, 全 4 回の講義で周知した。な お，講義時間 90 分あたりの資料全体の平均文字数は 3 , 352 文字であり, 重要部分の文字数は全体の $8.9 \%$, 予告 した出題部分の文字数は全体の $4.7 \%$ であった.

試験は 90 分 83 問, 100 点満点で, 問題形式は空欄に適 切な語句を記入させたり, 図示して説明させたりするも のとし，講義資料で出題予告した部分を漏れなく出題し た. 採点後, 成績評価は $\mathrm{S}(90 \sim 100$ 点), A ( $80 \sim 89$ 点), B ( $70 \sim 79$ 点), $C$ ( $60 \sim 69$ 点), $D$ ( 59 点以下) 05 段階に分 類した.

試験終了直後, 図 1 亿示すアンケート調査を実施した。 学生の自己評価による学習意欲, 学習時間, 達成感につ いては, 試験出題部分が知らされない他の講義と, 出題 部分が予告された今回の講義を比較するため, $100 \mathrm{~mm} の$

1 群馬県前橋市昭和町3-39-15 群馬大学大学院医学系研究科総合医療学 2 群馬県高崎市中大類町 37-1 高崎健康福祉大学 平成18年 8 月 14 日 受付

論文別刷請求先 テ371-8511 群馬県前橋市昭和町3-39-15 群馬大学大学院医学系研究科総合医療学 田村遵一 

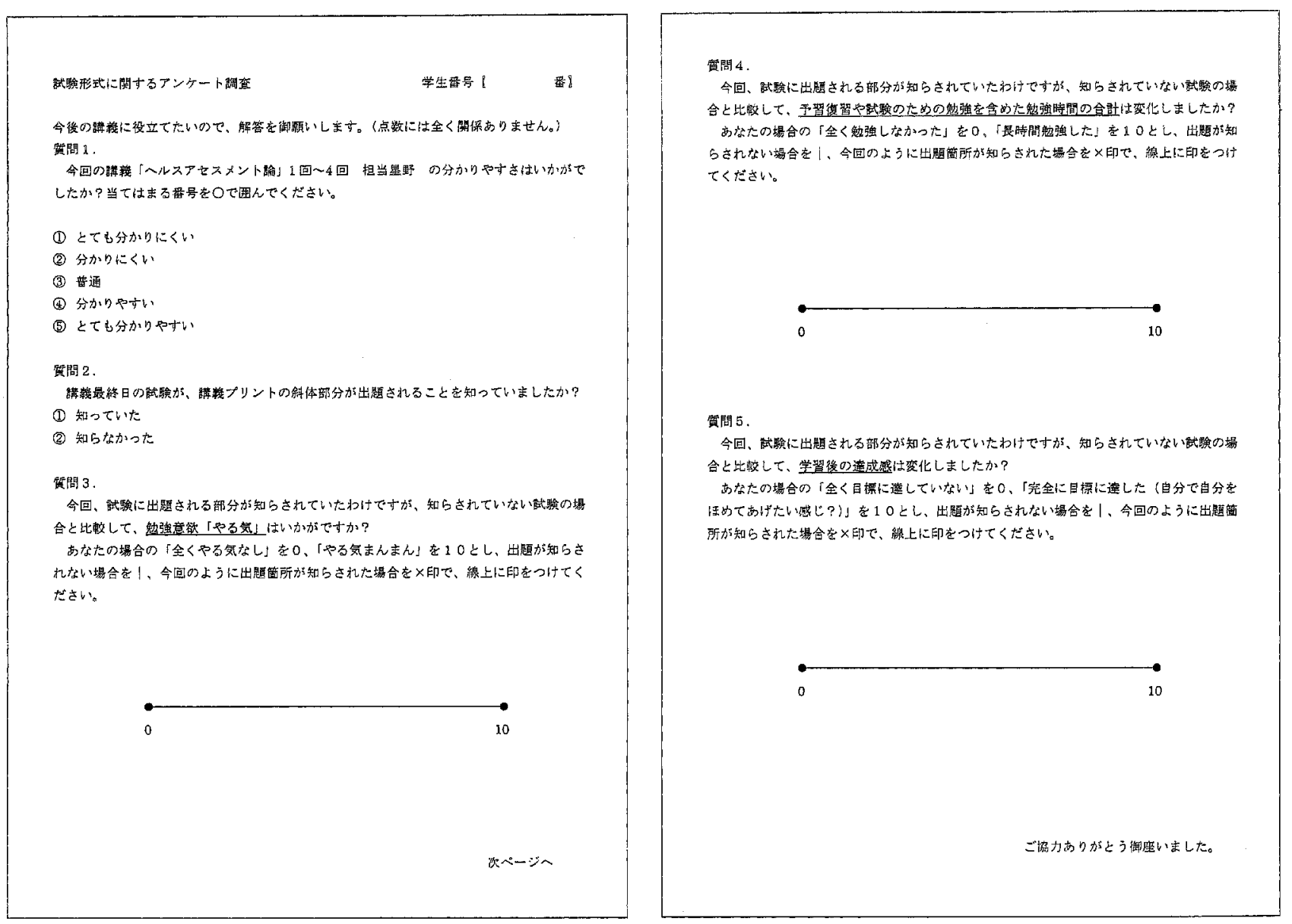

図 1 試験形式に関するアンケート調査

表 1 自由筆記のアンケート結果 $(n=84)$

\begin{tabular}{|c|c|c|c|}
\hline 今回の講義で良かった点に関する項目 & $\%(川$ 順位 $)$ & 今回の講義で改善すべき点に関する項目 & $\%$ (順位) \\
\hline 口 講義内容·方法に関する項目 & & 講義内容·方法に関する項目 & \\
\hline 分かりやすかった & $52.4(1)$ & 講義時間が少なくて残念だった & $16.7(8)$ \\
\hline プリントが良かった & $50.0(2)$ & 集中したいので私語する学生にもっと注意してほしい & $15.5(10)$ \\
\hline 授業内容が充実していた & $10.7(15)$ & 実習と講義を平行して行ってほしい & $9.5(16)$ \\
\hline 黒板に描いた絵や図がよかった & $6.0(18)$ & 試験出題部分と重要な部分をさらに強調表記してほしい & $4.8(19)$ \\
\hline 口 学習意欲に関する項目 & & 覚えることが多くて大変だった & $3.6(20)$ \\
\hline 講義が楽しみだった & $29.8(3)$ & 5次元目の講義で眠いので発害機会を増やしてほしい & $3.6(20)$ \\
\hline 看護学を学んでいるといら実感をもった & $21.4(4)$ & プリントの難読用語につける振り仮名を増やしてほしい & $2.4(22)$ \\
\hline 今まで学んだことの復習が必要だと感した & $17.9(7)$ & ビデオなどの画像を講義に取り入れてほしい & $2.4(22)$ \\
\hline もっと学ばなければという自党をもった & $16.7(8)$ & 黒板に描く絵や医をもっと增やしてほしい & $1.2(24)$ \\
\hline 実習で学習内容を実践するのが楽しみになった & $15.5(10)$ & 講義の合間に話した臨床の体験談をもっと聞きたい & $1.2(24)$ \\
\hline 講義内容がとても重要なものだと感じた & $15.5(10)$ & 他の科目も今回のような講義がいい & $1.2(24)$ \\
\hline 今後もがんばりたいと思った & $13.1(13)$ & プツントの講義上り黒板を自分でノートに取る方が覚える & $1.2(24)$ \\
\hline 勉強して機序を理解することの重要性を自覚した & $11.9(14)$ & n 学習意欲に関する項目 & \\
\hline 详成感に関する項目 & & 試験に出るところがわかっていない方が緊張して德くと思う & $1.2(24)$ \\
\hline 講義が自分のためになったと感じた & $19.0(5)$ & 達成感に関する項目 & \\
\hline 今までの学習内容があらためて理解できた & $7.1(17)$ & 講義内容が難しくてついて行けなかった & $1.2(24)$ \\
\hline 口 試験に関する項目 & & 口 試験に関する項目 & \\
\hline 試験に出るところが分かっていて勉強し易かった & $19.0(5)$ & 試験の解答欄をもっと大きくしてほしい & $1.2(24)$ \\
\hline
\end{tabular}


Visual analogue scale (VAS) を用いて定量化した.なお， アンケート項目のうち自由筆記の内容に関しては，学生 が取り上げた項目を抽出し, 表 1 に示すように学生 84 名全ての回答を集計した.

統計解析を行う際, 試験出題部分が予告された場合と 予告されない場合の VAS 值の比較には paired t test を 使用した. 解析には統計パッケージソフトDr.SPSS ${ }^{\circledR}$ を 使用し, $\mathrm{p}<0.05$ を有意水準とした.

\section{成 績}

試験の得点は $84.5 \pm 15.1$ 点 (平均土標準偏差) で, 成績 評価は S42 名 (50.0\%), A 15 名 (17.9\%), B 17 名 (20.2\%), C3 名 (3.6\%), D7 名 (8.3\%) であった. 講義への出席率は 97.3\%であった.

アンケートの回収率は $100 \%$, 有効回答率は $89.3 \%$ で あった。

アンケートの結果，今回の講義が「とても分かりやす い」あるいは「分かりやすい」と回答した学生は $75.0 \%$
であった (図 2). また, 試験問題が講義資料に予告されて いることを知っていると答えた学生は 94.0\%であった。

試験出題部分が予告された場合と予告されない場合 の, 学生の学習意欲, 達成感, 学習時間の VAS 值を図 3 に示す. 学習意欲は, 試験出題部分を予告した今回の講 義の方が, 予告をしない他の講義よりも, 有意に高かっ た (予告なし $43.5 \pm 26.2 \mathrm{~mm}$, 予告あり $73.1 \pm 19.5 \mathrm{~mm}, \mathrm{p}<$ 0.001).なお，試験問題の予告により学習意欲が低下した 学生は 5 名 $(6.0 \%)$ おり, 成績評価の内訳は $\mathrm{S}$ が 4 名と $\mathrm{A}$ が 1 名であった. 達成感は, 試験出題部分が予告され た場合が，予告されない場合に比較して有意に高かった (予告なし $42.8 \pm 27.3 \mathrm{~mm}$ ，予告あり $59.1 \pm 25.6 \mathrm{~mm}, \mathrm{p}<$ 0.001). 学習時間については試験出題部分の予告の有無 による有意の影響を認めなかった。

次に, 試験出題部分予告の有無により特に差が認めら れた学習意欲について，成績評価別の集計を行ったとこ ろ，成績評価の高低にかかわりなく，試験出題部分を予 告した今回の講義の方が, 予告をしない従来の講義より

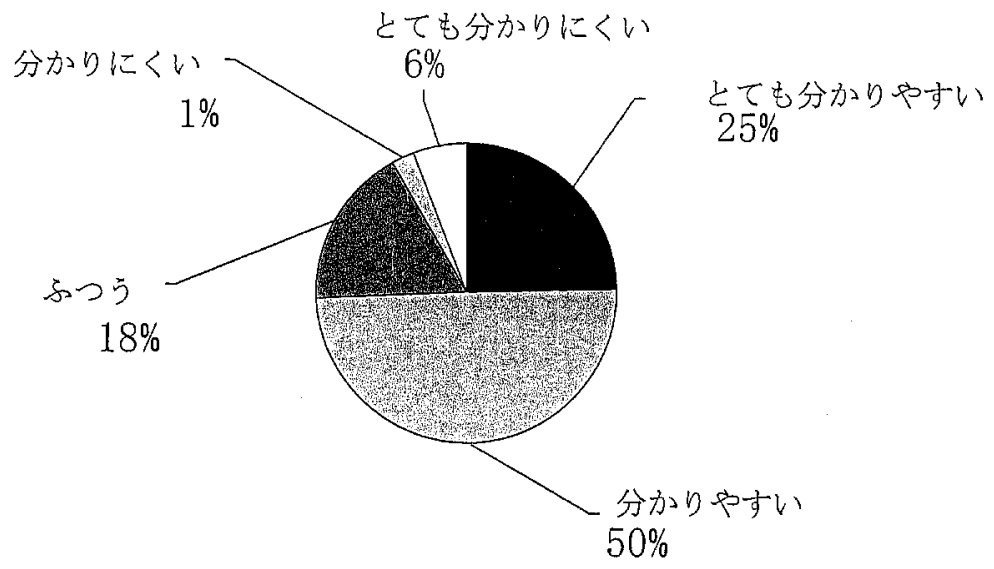

図 2 講義の理解しやすさ

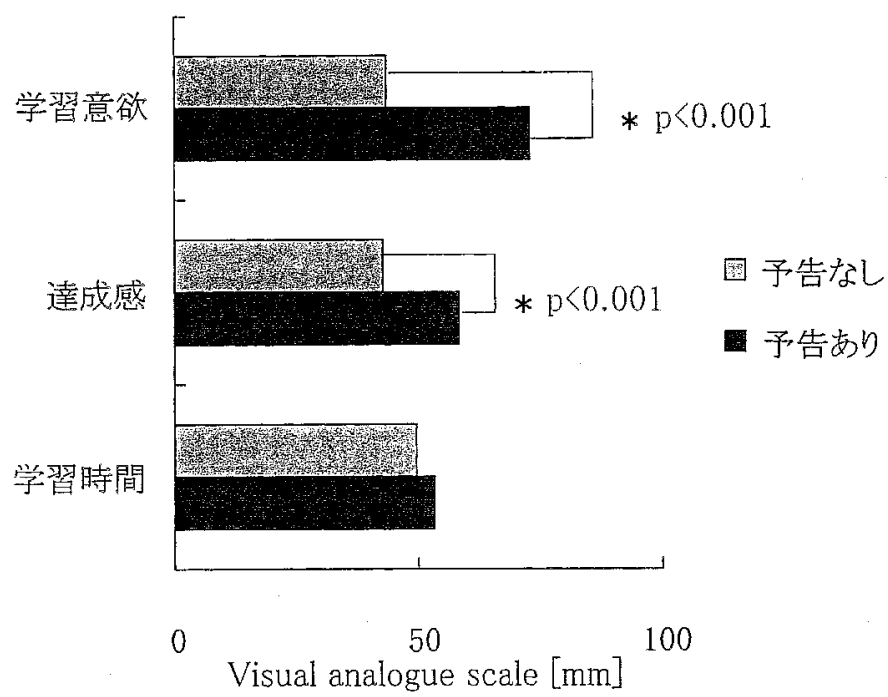

図 3 学習意欲・達成感・学習時間に対する試験出題部分予告の影響 


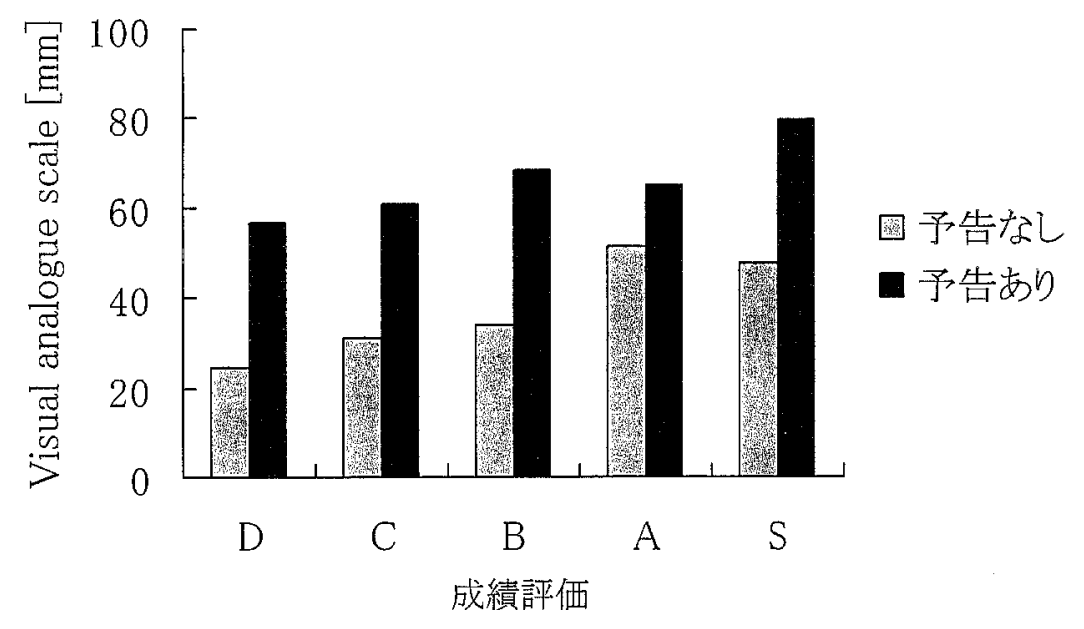

図4 成績評価別にみた学習意欲に対する試験出題予告の影響

も学生の学習意欲が高い傾向がみられた (図 4). また, 今 回の講義に関する成績評価と学習意欲, 達成感, 学習時 間の相関を求めたところ, 高い評価を得た学生ほど高い 学習意欲を自覚して扔り (相関係数 $0.32, \mathrm{p}<0.001$ ), 長時 間勉強したと感じて抢り (相関係数 $0.40, p<0.001$ ), 達成 感も高かった (相関係数 $0.47, \mathrm{p}<0.001$ ).

自由筆記のアンケート結果を表 1 亿示す. アンケート から抽出された項目は全 30 項目で, 内容は大きく「今回 の講義で良かった点」と「今回の講義の改善すべき点」 の 2 つ括られ, この 2 つのカテゴリーの中でそれぞれ 「講義内容・方法」,「学習意欲」,「試験」,「達成感」に関 する4つのサブカテゴリーに集約された．

主な分析結果としては, 「今回の講義で良かった点」の カテゴリーのうち「講義内容・方法」のサブカテゴリー に属する「分かりやすかった $(52.4 \%, 1$ 位, 学生数の割合 とその順位. 以下同様)」,「プリントが良かった (50.0\%, 2 位)」の項目が全項目中上位 2 項目を占めた. また, 「今回 の講義で良かった点」では「学習意欲」のサブカテゴリー に属する項目数が 15 項目中 8 項目と最も多く, これら 8 項目は全項目中でみても上位 15 項目のうちにはいって いた. 主な項目としては「講義が楽しみだった $(29.8 \%, 3$ 位)」,「看護学を学んでいるという実感をもった $(21.4 \%$, 4 位)」,「今まで学んだことの復習が必要だと感じた (17.9\%, 7 位) 」,「もっと学ばなければという自覚をもっ た ( $16.7 \%, 8$ 位)」,「実習で学習内容を実践するのが楽し

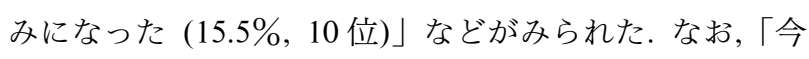
回の講義で良かった点」のうち, サブカテゴリー「達成 感」に関する項目には「講義が自分のためになったと感 じた $(19.0 \%, 5$ 位)」が認められた。

一方,「今回の講義の改善すべき点」のカテゴリーには, 「講義内容・方法」のサブカテゴリーに属する項目数が多 く (15 項目中 12 項目), その主な項目は「講義時間が少な くて残念だった (16.7\%,8位)」,「集中したいので私語す

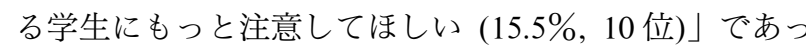
た.

\section{考察}

どうしたら学生の学習意欲を引き出せるかは看護の学 生教育における最重要課題であり, 学習意欲そのものの 解釈や, 学習意欲を形成する因子について, 数多くの研 究が行われてきた，それによると，「看護の専門性・自尊 志向」「実用・充実志向」,「看護への興味・関心」などが 学習意欲を形成する因子として重要とされている. ${ }^{2-4}$ 今 回, 我々が担当した「ヘルスアセスメント論」とは,引き 続いて行われる実習室での演習と, 病院や施設での臨地 実習に向けて, 診察技法の裏付けとなる最低限の知識と 用語を短時間で身に付けることを目標とする講義形式の 授業である. 講義回数は 4 回と少なかったものの, 学習 すべき知識や用語の数量が限定されているため, 十分な 内容解説と試験出題部分の予告が可能であった. 講義の 工夫として，上述の学習意欲を形成する因子をできるだ け多く取り入れるよう心掛けた. 第一に, 学生が習得す べき専門知識を明示することによって, 将来の実習でそ の専門知識を駆使する必要があるのだという看護の専門 性をはっきりと自覚させた。第二に，試験に合格するた めには明示された部分を覚えなければならないが，そこ で覚えた知識と用語は将来の実習にも必ず役立つのだと いう実感を持たせた. 第三に, 試験には出題しないが理 解を深めるのに必要な知識や事例を重要部分として明示 することによって, 学生の興味と関心を喚起した。

これらの工夫を施した結果, 学生の成績は出題者の予 想を大きく上回り, 全体の $91.7 \%$ が 60 点以上の合格点 を獲得し， 80 点以上の好成績をあげた学生は全体の 67. 9\%にも達した. このような好成績の背景には, 試験出題 部分を予告した今回の講義では，それを予告しなかった 他の講義に比べて, 学生の学習意欲と達成感が有意に高 
かったことが一因としてあるのではないかと思われる， 自由筆記のアンケートからの項目抽出でも, 上位 15 項 目のうち 8 項目を学習意欲の向上に関する項目が占める など, VAS スケールで測定した学習意欲の高さを裏付け る結果であった。また，抽出項目には「看護学を学んでい るという実感を持った」，「実習で学習内容を実践するの が楽しみになった」などの看護学生ならではの感想が多 数みられ，学生が講義の趣旨を正しく理解できたことが 替元る. 以上から, 試験出題部分の予告は, 学生の学習意 欲と学習後の達成感を高める効果があり, 今回の講義の ように「最低限の知識と用語を短時間で身に付ける」こ とが要求される教育場面では極めて有効な手法であると 考元られた

一方, 試験出題部分の予告によって, かえって学習意 欲が低下したとする学生も全体の $6.0 \%$ にみられた.こ れらの学生は成績評価で $\mathrm{S}$ や $\mathrm{A}$ などの好成績を得てお り，自由筆記のアンケートでも「分かりやすかった」,「プ リントが良かった」など，講義に肯定的な意見が多くみ られたことから，学習目標に対して余力のある優秀な学 生であった可能性がある. 今後は, これらの優秀な学生 においても学習意欲を高く維持しつつ十分な達成感が得 られるよう, 講義と試験の内容に一層の工夫を凝らす必 要があると思われた.

なお, 本研究にはいくつかの限界が存在する. 第一に,
試験出題部分を予告しない対照群を同一条件で設定する ことが不可能であるため, 今回の講義を，同時期に行わ れた, 試験出題部分を予告しない他の講義と比較するこ とによって, 試験出題部分の予告の有無による相違を検 出しょうとした点である.このため, 本研究は正確な意 味の比較対照研究とはなり元ず, 結果の解釈には慎重さ が要求される. 第二に, 「学習意欲」,「達成感」,「学習時 間」の比較にはVAS スケールを用いて,アンケート (図 1) の質問から学生が想起する主観的なイメージを定量 化したが，その程度の高低を左右する因子は学生によっ て異なる可能性がある.このため, 類似の研究を行う場 合に有効かつ簡便で再現性のある方法の開発について更 なる検討が必要である。

\section{文献}

1. 但島まり子. 看護教師の思い一学習意欲を引き出す試 み. 看護展望 $2003 ； 28 ： 1064-1065$.

2. 永嶋由理子. 看護学生の学習意欲の検討. 山口県立大学 看護学部紀要 $2001 ; 5: 39-45$.

3. 菊地昭江. 看護学部 1 年生の学習意欲と学習時間の関 係. 日本看護研究学会雑誌 $2000 ； 23: 325$.

4. 菊地昭江. 看護学部 1 年生の学習意欲と学習時間扔よ び学習理解度との関連. 東京女子医科大学看護学部紀要 $1999 ; 2: 29-34$ 


\title{
The Preannouncement of Exam Questions in Printed Synopsis of Lecture that Increase Motivation for Learning among the Student Nurse
}

\author{
Ayami Hoshino, ${ }^{1}$ Hironosuke Sakamoto, ${ }^{2}$ Jun'ichi Tamura, ${ }^{1}$ \\ Masako Seto ${ }^{2}$ \\ 1 Department of General Practice Medicine, Gunma University Graduate School of Medicine \\ 2 Faculty of Nursing Takasaki University of Health and Welfare
}

Background \& Aims : The student nurse is required to acquire comprehensive knowledge of nursing with a strong motivation for learning. In this study, we tried to increase motivation for learning among the student nurse by the full and particular preannouncement of the exam questions in printed synopsis of lecture. Methods : The 1st year student nurses in the year 2004 (Men 12, Women 72) were included. We announced the exam questions in printed synopsis of lecture, and after exam, conducted a survey in the form of a questionnaire using Visual Analogue Scale about motivation for learning. Results: The questionnaire data established that the student nurse felt motivation for learning more strong in our lecture, than another lecture without preannouncement. The item "Hopes are raised to utilize the knowledge and learn in the clinical training" was extracted as one of the comment in student nurse, which freely expressed opinions of our lecture. Conclusions : We regard that the preannouncement of exam questions in printed synopsis of lecture is effective in increasing motivation for learning among the student nurse. (Kitakanto Med J 2006;56:313 318)

Key Words: preannouncement of exam questions, printed synopsis of lecture, motivation for learning, student nurse 